\title{
Machines to think with? E-books, Kindles and English teachers, the much prophesied death of the book revisited
}

Book or Report Section

Accepted Version

Goodwyn, A. (2013) Machines to think with? E-books, Kindles and English teachers, the much prophesied death of the book revisited. In: Goodwyn, A., Reid, L. and Durrant, C. (eds.) International perspectives on teaching English in a globalised world. National Association for the Teaching of English (NATE). Routledge, Abingdon, pp. 65-78. ISBN 9780415504461 Available at https://centaur.reading.ac.uk/37678/

It is advisable to refer to the publisher's version if you intend to cite from the work. See Guidance on citing.

Publisher: Routledge

All outputs in CentAUR are protected by Intellectual Property Rights law, including copyright law. Copyright and IPR is retained by the creators or other copyright holders. Terms and conditions for use of this material are defined in the End User Agreement. 


\section{CentAUR}

Central Archive at the University of Reading

Reading's research outputs online 


\section{Chapter 6}

\section{Machines to think with? E-books, Kindles and English teachers, the much prophesied death of the book revisited}

[6427]

Andrew Goodwyn, University of Reading, UK

\section{Introduction}

The claims for the 'digital revolution' in education have to some extent remained just that, rhetoric rather than reality, at least in schools. Although the use of mobile technologies by students has revolutionised adolescent life, schools as institutions have resisted adopting such technologies within the school walls [Sternberg, Kaplan and Borck, 2007]. There has also been much speculation about how literary studies and research would evolve but not at school level [see for example McGann, 2001, Schreibman and Siemens, 2008]. English teachers themselves seem well disposed to technological change and adoption [Goodwyn, 2011a] but very often they are working with a pre-digital curriculum and an assessment system that a nineteenth century teacher would recognise. The term 'computer literacy' has, now, been superseded by 'digital literacy' and some very valuable research has been done in the Subject English community, investigating the potential of teachers engaging with digital literacies in their classrooms. Much of this research has focused on how such literacy may signal a shift to the visual or how the interactivity of multimodal technologies may empower the creativity of adolescents. Equally, the death of the book, has been much discussed for decades [see Birkets, 2006, for a good overview]. There have, as yet, been few research projects focusing on e-readers in educational settings and their concern has not been 
related to English teachers [see for example Jones and Brown, 2011, Larson 2009, 2010]

A relatively recent and spectacularly successful innovation is the combination of the ebook with a hand held device designed specifically to read it, most famously the Amazon Kindle. At one level this is a curiously nostalgic step as the interface is designed to emulate black print on a white page. At another level this may be a tipping point for the way schools, and especially English teachers, welcome a digital device into their classrooms. This article reports on a research project which involved a survey of teachers followed up by interviews with 20 English teachers, undertaken with the support of National Association of Teachers of English (NATE). The research aimed to gauge the views and feelings of English teachers about the current, and future, impact of the Kindle and its increasingly numerous rivals. It speculates on the future of English teaching with this particular technological advance offering new and exciting possibilities for reading. For the purposes of depth this article presents the interview data in detail and briefly comments on the survey, that data has been reported on elsewhere [see Goodwyn, forthcoming 2013]

\section{E-readers and books}

English teachers 'love' of reading is well documented [for example, Goodwyn, 2003, $2011 \mathrm{~b}]$ as is their passionate devotion to the book as a material object. There is not space here to analyse this relationship much in depth, aspects of it emerge in the interviews [see below] and are remarked on in the discussion. It is important to note that English teachers are reflexive about their attachment to actual books and know it is a deeply personal and emotional factor but they clearly separate this factor from their 
professional wish to pass on a love of reading to all their students, they are aware that their own devotion to 'the book' may actually be a disincentive to new and future generations of readers. This personal/professional relationship is complex and fraught with tensions and feelings and so the e-reader can exacerbate the tension, but overall [see below], it is the professional and pedagogic dimension that dominates their views about the future of reading.

Certainly the success of the devices themselves deserves the term phenomenal although product information in terms of sales is hard to acquire. The very frequent degree of comment in the media [see for example, Ehrenreich, B, 2011] about them is perhaps sufficient evidence of their impact on reading. However, it would be wrong merely to assume familiarity at this stage of their development and so it is first important to describe what such devices can do. This is also significant because the research discussed below is based on the characteristics of these devices as understood in August 2012, given the very rapid pace of both change to particular models [such as The Kindle, a new touch device was launched in March 2012] and proliferation of devices such as the iPad and Iphone, then these characteristics are likely to be immediately dated. However, the very deliberate 'book-like' modelling of such devices suggests that some key characteristics are likely to be maintained and enhanced, rather than replaced.

The characteristics these devices tend to share are:-

- Looking 'book-like' i.e. about the size and shape of a page in a typical paperback fiction book; 
- Small size and portability being light in weight and thin and can be held comfortably in one hand;

- Having a screen which reproduces the look of a book i.e. black print on a white 'surface';

- Able to store a large number of texts [books, articles, documents etc.]

- Wi-Fi enabled, allowing for instant downloading of new texts

- Capacity to adjust font size, larger or smaller;

- Capacity to 'work on' the text e.g. highlight, annotate etc.

- Capacity to hear the text read using head phones;

- Constant access to a dictionary and an encyclopedia;

- Having a dictionary function that allows the instant provision of a word definition.

There are, already and rapidly developing, variants on these e-readers because mobile phones, I-Pads and other computer style devices also now emulate more book-like reading experiences, however, for the purposes of this article the discussion will almost exclusively focus on the e-readers that resemble The Kindle.

It must be stated that the familiarity of books is in itself misleading. They are obviously no more 'natural' than an e-reader and one might argue there is no natural reading. Books are produced by technology and, it might be argued, even the hand written texts produced pre-Caxton, needed a writing/painting tool and a suitable surface. Going further back to the inscriptions made on stone, these still required a made or adapted tool. Despite this and based on 'common sense' consensus, there are some distinct 
features of a book that an e-reader cannot replicate. The features of the modern book that are 'lost' in reading on an e-reader are:-

- The tactile dimension i.e. the weight and 'feel', usually two handed;

- The 'smell' of a book, which can be everything from clean and new to old and musty;

- The materiality of the page and its 'turning', and the capability of moving to any page via a physical action;

- The truly static text which never 'moves' i.e. the pages turn and readers move their eyes;

- The cover of the book and its numerous messages and signs. [This is a 'loss' felt strongly by bibliophiles who argue that a cover is an aesthetic artefact in itself and part, usually, of a book's 'beauty' and attractiveness. Again, there is an irony in that in the common parlance one 'should not judge a book by its cover'. It might be argued that the devotion to covers is part of an elite model of reading in which certain covers distinguish the 'classic' text from the 'trashy' novel and, since the early $20^{\text {th }}$ century much more to do with marketing than with aesthetics].

- The capacity to 'share' reading e.g. a parent reading to one or more young children - this is unlikely to be a long term difference as an e-reader could emulate the size and use of colour of a picture book, devices like I-pads already can do this; 
- A final point is that the remarkable speed with which a text can be selected and downloaded, by passes the settings in which 'real' books are housed such as a book shop, a library, a study, a simple book case.

The power of book collections is historically of great significance [Manguel, 2001] and it is multi-layered. Such collections were once only the preserve of the rich or the scholarly. They were, in themselves, signals of some institutional or ideological stance, for example religious, political, artistic, they were potentially visual manifestos. For individuals they were statements of cultural identity. The invention of the 'Public Library' opened the world of books to the poor and underprivileged. It is an interesting point to compare an online catalogue with a book collection. In one way they are the same i.e. a collection of books arranged by someone, almost always in an order which reveals that order e.g. categories and authors alphabetically, in another way they differ in that the scale of the collection, its impressiveness is lost on-line however huge it actually might be, it is reduced to the size of a screen, libraries, especially large ones, evoke feelings through their size and substance.

The e-reader is therefore a rather hybrid device, it is genuinely a new use of technology with some innovative features but it deliberately disguises its technological character by emulating bookishness. As with most technological developments, it was not specifically designed with teachers or the classroom in mind, this may of course change with 'education friendly' versions but currently its pedagogical uses would come via the adaptiveness of teachers. However, given the relationship of English teachers' with 
books, exploring their viewpoints of e-readers is useful in speculating how these developments may be used in the classroom in the future.

\section{Theoretical perspective}

In reporting the findings from this small scale research this paper draws on two key perspectives. The first is phenomenological [Cohen, Manion and Morrison, 2007], in that the meaning is understood, and made sense of, as reported by those that experience that in which we are interested .

The second informing perspective is that of Reader Response theory in which Rosenblatt [see Rosenblatt, 1995] argues that the text, especially the aesthetic text, is a dynamic entity created in a transaction between the reader and the text they are in the act of reading. This perspective emphasises the experiential nature of reading. Previous research demonstrates that this is the key view of English teachers that underpin that 'love of reading' and also influences their pedagogical approach to teaching literature [Goodwyn, 2003] . It can be argued, certainly in England, that Reader Response [not a term used much by teachers in England] is embedded within a Personal Growth pedagogy ${ }^{1}$, an approach which is explicitly espoused by English teachers. There will be some discussion [see below], about how this pedagogy relates to a conceptualisation of the 'lifeworld' of young people. This research was therefore interested in how teachers would comment on the reading experiences they personally had using E-readers and also their mostly speculative views about students' experiences.

Despite the comments above about the relationship between English teachers and the physical nature of 'real books', they also love the experience of reading. This might usefully be summed up as being 'lost in a book' i.e. when the intensity of the reading 
experience is such that the material world fades away and the reader enters the 'world of the book' and is completely absorbed. This is a psychological state in which the physical book becomes simply the text on the white page and the reader simply turns the page in an automatic way, fully absorbed in the experience happening as a mental state. This being the case, then it may be theorised that the e-reading experience can provide exactly the same 'experience' as the physical book. To put this simply, Rosenblatt was not describing 'book response' theory but reader response, the dynamic transaction between the reader and the text itself. The discussion below reviews this possibility based on the responses of the participants.

Finally, although this paper is placed within the context of a discussion of the digital revolution, there is no space for a discussion of the emergent fields that may be characterised as 'e-learning theory' or 'digital design'. E-learning theory seems currently concerned with adapting a range of well-known theories e.g. behaviourist, cognitive, constructivist etc. and applying them to technologically oriented activities, for a useful overview see Dyke et al (2007) and Haythornwaite and Andrews (2011, Chapter 2). Equally digital design, at least in Education, is concerned with the multifaceted relationship between 'users' and 'designers' where both sets of actors are often interactive, making a digital 'object' very different to traditional educational resources such as, inevitably, printed books, see Seale et al (2007) and Beetham and Sharpe (2007) for useful reviews

\section{Methods}

Previous research [Goodwyn, 2010, 2011b] might suggest a number of predictable 
reactions from English teachers about these 'book-like' devices but the approach taken was not to hypothesise but to enquire openly about their views and habits in relation to E-readers. The only suppositions assumed were that they would have an idea of what something like a Kindle was, and could do [given their high media profile and persistent advertising], and that, as a teacher of texts, they would have opinions about such devices; these assumptions were certainly correct in relation to the respondents, although the lack of overall returns [see below] may suggest this is not true of the majority of teachers. The approach in the research was therefore to treat E-readers as a phenomenon and to ask teachers their views both as personal readers and as teachers.

Data collection: Data was collected via an online survey of teachers of English using Survey Monkey. A sample of teachers were initially contacted via email using the National Association of Teachers of English (NATE) members list and invited to participate. NATE was chosen as a sampling frame as it is a voluntary subject association which represents the interests of both the subject and the teachers of English. In total 600 teachers were contacted and 137 participated in the online survey, giving a response rate of $23 \%$. Telephone interviews were conducted with 20 English teachers; selected at random from a sample of 60 teachers who had expressed a willingness to be interviewed. Whilst the sampling frame is unrepresentative in that it consists of members who are passionate about English, it also likely that these teachers are familiar with, and therefore have useful knowledge of e-readers and their potential impact in schools, thus their views are still valuable and using NATE as a sampling frame offers privileged access to that thinking.

The interviews were carried out via telephone and lasted between 30 to 45 minutes. Interviews collected data on personal and professional experience of e-readers as well as 
attitudes to the use of e-reading devices in the teaching of English more generally. Where applicable interviews also explored examples of current teaching practice using e-readers and reflected on the potential value of these in relation to more traditional methods of teaching in the future.

Sample: Of those included in the survey, $81 \%$ of teachers were female and $19 \%$ male. Seventy three percent of these are working in secondary schools; $7 \%$ in primary, $16 \%$ in tertiary and higher education and $4 \%$ were retired. In terms of length of time teaching, fifteen percent have been teaching for less than 5 years; $37 \%$ between 5 and 15 years and $48 \%$ for 15 years and more. The age of respondents ranged from under 29 and up to 69 years of age, with most teachers aged between 40 and $49(27 \%)$.

Of those interviewed, 17 of the teachers were female and 3 male. All were teaching within the secondary sector in schools ranging from independent to comprehensive and academy. Length of time teaching ranged from an NQT $(n=1)$ to 30 years + experience and at least half of the sample had some English leadership responsibility; either in leading the department or in curriculum development. In terms of e-readers, half of the interview sample also owned an e-reader whilst the other half did not

Data analysis: The survey data was analysed in SPSS with frequencies of responses and cross-tabulations used to explore the data in the first instance. Using frequencies allow an overall picture of the data, whilst cross-tabulations enabled exploration of patterns and trends. Cross-tabulations were also carried out on some of the key variables of interest and within sub-sets of the data to explore relationships between responses.

Most of the open ended data from the survey was coded to enable key themes to be identified. 'Free' or open coding was applied initially to themes relating to, for example, 
positive and negative attitudes to e-readers. Data was also categorised inductively in response to emergent themes arising through the first stage of the coding process. Data was coded by two separate coders and the results of the coding process were then compared. Comparing the similarity and difference in the coding process allows for a degree of confidence both in the reliability and validity of the codes identified and with their application to the rest of the data. Once coded, data was then transferred into SPSS for further analysis.

After transcription, interviews where explored using a grounded approach to analysis: a process of iteration which focused emphasis on the narrative and the discourse of responses. Data was then categorised in relation to the emergent themes arising from this process. So as not to lose meaning, this data is presented in its qualitative form. In carrying out this research all ethical procedures and guidelines were complied with as directed by The University's Ethics Committee and the British Education Research Association.

For the purposes of this paper the key themes drawn on are those that relate teachers' views on the potential value of e-readers in terms of their usefulness in teaching English and perspectives on the development of e-readers in the future of English teaching.

\section{Results}

\section{Usefulness of e-readers in teaching English}

Only $15 \%$ of teachers surveyed had e-readers available in their schools and even less currently used them in their teaching. However, just over half stated they would like to 
use them in their classrooms if they were available. In terms of perspectives on the broader value of e-readers in the teaching of English attitudes were largely positive. More than two thirds of teachers thought they would be a useful addition, with one third believing they would actually make teaching easier. Whilst there was some uncertainty as to whether these would prove distracting for students; make teaching more difficult or actually engage more students with reading, a far larger proportion of teachers felt the opposite would be true.

A cross tabulation indicated that there was no noteworthy association between positive attitudes to e-readers and owning one. As one might predict teachers that did not have a device were more likely to be unsure as to how useful they would be, and those that did, a little more positive.

All of the teachers interviewed could see the value of using e-readers in their teaching regardless of whether they owned one or not. When asked why, most referred to the specific, practical functions as explicit advantages that would make teaching more convenient and for some, aid confidence:

...they are easier from a reference point of view, um ......you know, take for example doing Curley's wife in 'Of Mice and Men', I spent about three hours going through three different editions of Mice and Men to find where she appeared in the book whereas in an e-reader I just tap in Curley's wife and find every page she appears on, so from that point of view, manageability (Male, 6 years teaching, secondary school) 
...the ability to look up those words you don't know... we tend to just skip over those don't we, and continue reading? (Female, 9 years teaching, secondary school)

...in terms of also being able to search through, as I do with one iPad for the whole class, being able to search through and find quotes...You know, if they are looking at a particular character, they can find lots of quotes to do with that character. [You] can track what's happening with that character through the book (Female, NQT, secondary)

...I use my interactive whiteboard an awful lot in my classroom and I also have a pad that I write on at the back of the classroom so that I can annotate text... with the Kindle app you can download all your notes that you've written....so you can share all of that with the children, so they can see exactly what you've got....so it adds to the annotation and also your confidence as a teacher... and you can show them, say, if you are searching for the word 'fear' in Mice and Men, I just did that, it's like, "how often does it turn up", things like that...it's a fantastic tool to be able to analyse a text, take it apart and put it back together again (Female, 15 years teaching, secondary school)

The only negative feature referenced by several teachers was a lack of page numbering: 
I don't like the time it takes me to find a specific page, I know you can put in bookmarks and things, but ..um..it's easy to say to a group turn to page 37, but not so easy to find that page in an e-reader because they are not numbered (Female, 10 years teaching, independent school)

Using e-readers in teaching was also considered as being very much at a developmental stage and issues around the costs for downloading texts for use in school an area as yet unexplored in terms of commercial viability:

I mean I would like to be able to have some deal with Amazon whereby you could buy, you could have a class set in effect, and to buy the book once might be slightly more expensive, but then you could download it to be used in class. And that kind of thing would allow you to be a lot more adventurous with the text you used because it wouldn't be such a huge commitment in terms of purchasing power and storage space, which is increasingly an issue. (Female, 10 years teaching, secondary school)

Interestingly, whilst the ability to access and store a range of books was considered as $\mathrm{s}$ key advantage, when referring to the value of e-readers more broadly, teachers overwhelming took a very student centred stance, with most indicating the ways ereaders can support student learning: 
I often feel that if you give a year nine student a really thin book because that matches their reading ability they're looking around at their peers going well how come they've got a bigger book with smaller writing in it, whereas with an e-reader you don't have that discrimination, it's just a flat screen.

(Female, 12 years teaching, academy school)

... the voice facility...on Kindles....there's a function where it will actually read aloud the text...this is good for slow readers who can hear the text being read aloud to them in their own time (Male, 20 years teaching, secondary)

Overwhelmingly, reluctant readers, and boys in particular, as well as students with visual disabilities, were the groups of students who were perceived as benefiting most from the use of e-readers in English. Some teachers' referenced specific examples of how these were currently already being trialled with targeted groups of students in their schools:

...at the moment, I am working with the most reluctant readers in our year eight, um.... once a week those students are pulled out, to read with the sixth formers, to develop their reading skills. But rather than reading on books, which they've traditionally done, they're reading with e-readers, they're on Kindles, and I'm kind of gauging their interest levels and how, how motivated they are as a result of that. Yeah, it's increasing interest, but it's not an absolute remedy because it's still reading to them. But it's 
definitely...it holds a lot more street cred........ being with a gadget as opposed to a book. I think they actually enjoy...trivial as it sounds....they enjoy the clicking of the buttons. And.....they enjoy making the text bigger. (Female, 4 years teaching, secondary school)

I know that we've, we have actually invested in a couple of iPads as a trial to see how they're helpful for, particularly students who have reading issues. They are very good when they are trying to catch up on reading (Female, 10 years teaching, secondary school)

We've got 4 kindles which are on loan to us by the library service, so we've done a variety of different things with them. One teacher is using them actually...in connection with the Reading Champion's Club and she's trying to get more boys reading. Inside the classroom we use them for just independent reading time within the classroom, so when they bring in their own books, they take turns in having access to the Kindles, they enjoy that part of it, and I've also started using them to...... when they're reading in small groups, when they're reading the class texts, they will take turns in being in charge of the Kindle and of looking up any words that the group doesn't understand. They enjoy that. And they also have the opportunity to then, highlight passages relating to certain themes, and make notes, which I'll then print out and photocopy them for the whole group. So were trying to use them in school. (Female, 3 years teaching, secondary school) 
From both survey and interviews it was clear that e-readers were considered as having great potential. Implicit in teachers' comments was a sense that their real value however was still to emerge and that the role of e-readers in the classroom was still very much at an embryonic stage of development. Interestingly, whether teachers owned a device or not, all were able to anticipate the significance of these, even if noted with hesitancy and caution by some.

\section{E-readers and the future development of English Teaching}

More than three quarters of teachers consider that e-readers will become important in schools in the future; with $61 \%$ believing they will also become increasingly useful in the classroom and in the teaching of English in particular. Interestingly, almost all of those surveyed also felt that there will be a growing expectation to use them.

Three quarters of teachers predict the prospect of a growing emphasis on using media devices in teaching as a result of student expectation. A view that resources would make it more probable was also the opinion of more than half of teachers. Interestingly, parental or government expectations appeared to matter far less, in terms of their capacity to influence the future.

$64 \%$ of teachers also felt the curriculum was likely to change to include the use of ereaders, yet only a small number of teachers saw this as a potentially negative development. In interview teachers were asked to speculate on this potential 
development and what the implications of this might be. Overwhelming, teachers did envisage that e-readers would become part and parcel of teaching, articulating a view that within the natural evolutionary process of teaching, it was inevitable. More implicitly, the idea that schools are a microcosm of society, reflecting broader social changes was also eluded to:

Yes, just because I think our reading habits are shifting, I think globally reading habits are shifting. You can see people on the train using e-readers and it's just going to become.....I think we will just shift. I think it's a bit like the shift from paper, we haven't given up paper, we still do lots of paper based exercises in schools, but we do word processing, it's just we do it as a matter of course and we expect everybody at home to have a word processor and I think at some point, we will probably have that expectation that people can just go and access a book via an e-reader. It will become part of life.

(Female, 15 years teaching, secondary school)

In addition, the perceptions of the value of the pedagogic features were also seen as a key contributing factor to an increasing focus on their use:

....they just provide an opportunity to be more innovative in the classroom (Female, 3 years teaching, secondary school)

I think it will be another item in the toolbox and I think variety is always important. You know. It is important too, I think, yeah children enjoy difference and I think if you can get as much variety into teaching as 
possible, then... it will have a place. (Male, 25 years teaching, secondary school)

Again, pragmatic considerations featured heavily in teachers' ruminations:

we are much more aware of - you know we are much more ecologically minded and books being thrown away, you know, it's a terrible sin, but they just wear out. Um...I don't know how schools will do that but I can certainly see that happening. You know you need fewer storage cupboard. Logistically, the benefits are huge. (Female, 10 years teaching, secondary) I think it's probably inevitable ...certainly the devices that we use, you can actually download a book and then you can sync that book across several devices that you've got. So you only buy the book once. So once you've invested in the devices, it's actually a much cheaper way to buy the literature (Female, 4 years teaching, secondary)

However, specific issues featured heavily in teachers views on the ease with which ereaders will embed in to teaching. Concerns around the durability, security and general maintenance of the devices were highlighted as were issues of accessibility: ...there are issues with the buying of the books, and the setting up of the accounts and that sort of thing, so, we're finding that Finance who typically have to fill in an order form, um.. aren't as ofay with the IT side of things, so 
you're having to get the IT department to work with the Finance department to actually get the books on the devices, and then we've also had some issues with the protection of the devices, both in terms of having wi-fi disabled, or needing to have wi-fi disabled, so that the students aren't trying to access the Kindle accounts. Umm..... And also, obviously, they're expensive devices, so any damage that may be caused to them by the students is a concern. Or theft could be a concern as well. We've also had some issues with the logistics of getting them charged up, and trying to find a safe place for them to sit on charge, that is away, locked away from the students, but is still accessible to teachers. (Female, 3 years teaching, secondary)

Um...I think obviously you have to make sure that it's fair that all students have them. If it something that has to be provided by the student, then obviously poorer students are going to lose out to wealthier students. Also there's got to be an issue of control as well, about are students going to be given out e-readers, like you would give out a novel now and then have it collected back, or can they have them in school all day, and will they have them to take back home, or who does it belong to and who controls what software's. And issues of are they going to break as well.

Interesting, some teachers felt that, as yet, there was not enough research evidence to support an adoption of e-readers into the classroom: 
it would be nice if there was some kind of local authority funding into putting e-readers into schools and trialling them and seeing the response and seeing what happens, there seems to be a lot of funding available for laptops ..um ...but not for, you know, the whole e-reader thing, I think it's still under the radar a little bit. (Male, 7 years, secondary school) .....if the government or whoever's promoting this, thinks it's worthwhile, then they will throw money at it and we will be able to use e-readers, but I don't know whether we need to have some evidence that these e-readers have great benefit. I don't think we have that now do we? (Female, 10 years teaching, secondary school)

Regardless of the relative merits of e-readers and the many ways that these may and do prove useful in teaching English, as one teachers notes, the key will always be the teacher '...ultimately, it's actually the interaction with the teacher that is moving them on' (Female, 10 years teaching, secondary school)

\section{Conclusions}

Overwhelmingly, teachers did envisage that e-readers would become part and parcel of teaching, articulating a view that within the natural evolutionary process of teaching, it 
was inevitable. More implicitly, the idea that schools are a microcosm of society, reflecting broader social changes was also a factor.

Implicit in teachers' comments was a sense that their real value however was still to emerge and that the role of e-readers in the classroom was still very much at an embryonic stage of development. Interestingly, whether teachers owned a device or not, all were able to anticipate the significance of these, even if noted with hesitancy and caution by some. This point illuminates teachers' professional commitment to developing students' reading even when there may be tensions with their own 'love' of conventional reading habits.

Interestingly, some teachers felt that there was not enough research evidence to support an adoption of e-readers into the classroom, perhaps indicating a willingness to undertake some action research themselves if provided with an opportunity.

Regardless of the relative merits of e-readers and the many ways that these may and do prove useful in teaching English, as one teachers notes, the key will always be the teacher '...ultimately, it's actually the interaction with the teacher that is moving them on'. This suggests a residual confidence in the teacher's role. This new technology is not perfect and has some practical problems, but the teacher can remain the designer of reading opportunities and experiences and make the most of the enhanced feature of the e-reader device.

Overall it is very clear that English teachers sense enormous positive potential for groups of readers who have found the traditional models of reading very negative, especially in overcoming some of the physical limitations of the book. This potential inclusivity is highly rated. Equally, there is a strong conviction that e-readers work with 
the grain of adolescent life, they can be seen as part of the life worlds of young people, something vital to English teachers generally [see Goodwyn, 2011a]. It can be inferred that E-readers are seen as a close fit with a Personal Growth model of English which privileges an individual's development and the nurturing of imaginative and aesthetic development [For English teachers longstanding loyalty to Personal Growth, see Goodwyn, 2010].

Further research will be needed to examine whether these speculations can be carried into daily practice, case studies of classroom practice would be ideal. There will also need to an examination of interventions - do -e-readers increase motivation, motivate particular readers, increase length of time reading, or generate improved reading comprehension? Kindles are very popular but some comparative research on differing forms of e-reading will be very aluable? For example the use of I-pads will be important. And such research may need to be sited in larger trends such as changes to reading habits and the economics of reading, both personal and in schools and other education organisations.

What this research suggests is that English teachers are ready, and very willing, to explore a new form of reading that they believe will enthuse many reluctant readers and also provide more opportunities for young people to value their interactions with texts.

\section{References}

Beetham, H. and Sharpe. R (2007) [eds] Rethinking Pedagogy for a Digital Age: designing and delivering e-learning, London, Routledge.

Birkets, Sven, (2006) The Gutenberg Elegies: The Fate of Reading in an electronic age, London, Faber and Faber, London 
Cohen, L. Manion, L. and Morrison, K. (2007) Research Methods in Education, Routledge, London

DES (1989) English for Ages 5-16, London, HMSO

Dyke, M., Conole, G., Ravenscroft, A. and de Freitas S. 'Learning Theory and its application to e-learning', in Grainine, C and Oliver, M. pp. 83-97, (2007 ) [eds] Contemporary perspectives in e-learning research: themes, methods and impact on practice, London Routledge

Ehrenreich, B. April 18th, 2011) The Death of the Book, LA review of Books, Los Angeles http://lareviewofbooks.org/article.php?id=19\&fulltext=1, accessed May $15^{\text {th }}$, 2011

Goodwyn, A. (forthcoming, 2013) 'English teachers and e-readers', in New media and new learning, London, Sage

Goodwyn, A. (2011a) 'English teachers in the digital age - a case study of policy and expert practice from England', English in Australia, Issue 46, No 1.pp 52-63.

Goodwyn, A.( 2011b) 'Becoming an English Teacher: Identity, Self knowledge and Expertise, in Davison, J and Moss, J. Debates in English, Routledge Goodwyn, A. 2010 The status of literature: a case study from England, English in Australia, Vol 45, No. 1, pp18-28.

Goodwyn, A. (2010) The Expert Teacher of English, London, Routledge

Goodwyn, A., (2003) Breaking Up is hard to do: English teachers and that LOVE of reading, English Teaching, practice and critique, Vol 1, 1, September, 2003, pp 66-78 
Grainine, C and Oliver, M. (2007 ) [eds] Contemporary perspectives in e-learning research: themes, methods and impact on practice, London Routledge

Grudzien, P. \& Casey, A. M. (2008). Do off-campus students use e-books?

Journal of Library Administration 48(3/4), 455-466.

Haythornwaite, C and Andrews, R (2011) E-learning; theory and practice, London, Sage

Jones, T. and Brown, C. Reading engagement: a comparison between ebooks and traditional print books in an elementary classroom, International Journal of Instruction July 2011 Vol.4, No.2 pp. 5-22

Landow, G. P. (1994). Hyper/Text/Theory. Baltimore: Johns Hopkins University Press.

Larson, L.C. (2009). Digital literacies e-Reading and e-Responding: New tools for the next generation of readers. Journal of Adolescent \& Adult Literacy, 53(3), pp. 255-258.

Larson, L. C. (2010). Digital readers: The next chapter in e-book reading and response. The Reading Teacher, 64(1), 15-22.

Manguel, A. (1996). A History of Reading. New York: Viking.

McGann, J. (2001). Radiant Textuality: Literature after the World Wide Web. New York: Palgrave.

Negroponte, N. (1995). Being Digital. New York: A. Knopf. 
Rosenblatt, L.M. (1995). Literature as exploration (5th ed.). New York: AppletonCentury-Crofts Modern Language Association.

Schreibman, S. and Siemens, R. (2008) [ed] A Companion to Digital Literary Studies, Oxford: Blackwell, 2008.

http://www.digitalhumanities.org/companionDLS

Seal, J., Boyle, T., Ingraham, B., Roberts, G. and McAvinia, C. 'Designing digital resources for learning' pp. 121-133 in Grainine, C and Oliver, M. (2007 ) [eds] Contemporary perspectives in e-learning research: themes, methods and impact on practice, London Routledge

Sternberg, B.J., Kaplan, K.A. \& Borck, J.E. (2007). Enhancing adolescent literacy achievement through integration of technology in the classroom. Reading Research Quarterly, 42(3), p. 416-420 